\title{
The Relationship Between Family Functioning and Religiosity on Readiness for Change Among Persons under Surveillance
}

\author{
Siti Hazreen Shahrom ${ }^{1}$, Siti Aishah Hassan ${ }^{1}$, Engku Mardiah Engku Kamarudin ${ }^{1}$ \\ ${ }^{1}$ Department of Counselor Education and Counseling Psychology, Faculty of Educational Studies, Universiti \\ Putra Malaysia, Serdang, Selangor, Malaysia \\ Correspondence: Engku Mardiah Engku Kamarudin, Department of Counselor Education and Counseling \\ Psychology, Faculty of Educational Studies, Universiti Putra Malaysia, 43400 UPM Serdang, Selangor, Malaysia. \\ Tel: 603-9769-8210. E-mail: engkumardiah@upm.edu.my
}

Received: September 3, 2021 Accepted: September 28, 2021 Online Published: October 16, 2021

doi:10.5539/ass.v17n11p148

URL: https://doi.org/10.5539/ass.v17n11p148

\begin{abstract}
There are numerous theoretical perspectives on addiction and the behavioural change processes during the transition from addiction to recovery. Although the precise nature of the relationship between religion and family function has not been discovered, it has been highlighted as a significant component in addiction. This study examines the relationship of family functioning and religiosity on the readiness for change among Persons under Surveillance (PuS). We randomly selected respondents $(\mathrm{n}=85)$ of PuS in the National Anti-Drugs Agency (NADA), Jempol District, Negeri Sembilan, Malaysia, who participated in this study. Descriptive analysis was used to identify the level of family functionality, religiosity and readiness for change. Next, Pearson correlations were used to determine the relationship of family functionality to change and religiosity to the readiness for change. Findings showed a significant correlation $(p=0.00, p<0.05)$ between family functioning and readiness for change and it was a low positive correlation $(\mathrm{r}=+0.47)$. Moreover, findings showed a significant correlation $(\mathrm{p}=0.01, \mathrm{p}<0.05)$ between religiosity and readiness to change the relationship was a weak positive correlation $(\mathrm{r}=+0.27)$. In conclusion, family functioning and religiosity are related to readiness for change. This relationship is significant for PuS in NADA Jempol to implement self-care and for the divisional staff involved in NADA Jempol to develop prevention and rehabilitation strategies to prepare PuS out of the drug problem.
\end{abstract}

Keywords: family functioning, religiosity, readiness for change, persons under surveillance

\section{Introduction}

In Malaysia, the number of persons under surveillance (PuS) registered in the National Anti-Drug Agency (NADA) rehabilitation programme climbed dramatically from 46,139 in 2015 to 64,559 in 2017 (NADA, 2018). This steadily increasing trend shows that an increasing number of former addicts receiving treatment and recovery are being released under surveillance. They are depicted struggling to build a new life, maintain healing, and integrate into their environment and society. Generally, a PuS monitored by a Rehabilitation Officer is obliged to comply with the supervision order's criteria within two to three years, considering the client's commitment to the rehabilitation programme (NADA, 2018).

On the other hand, Othman, Idris and Druis (2017) revealed that a few PuS complied with the NADA's surveillance programme. PuS's efforts to overcome drug addiction require physical strength, a fighting attitude, and the support of family members and the surrounding community. In comparison, Jasni et al. (2018) discovered that ex-prisoners migrate due to the fragility of the social integration process between ex-prisoners and their families. The unfriendly relationship between families and ex-prisoners causes them to migrate and live separately and alone without the support of family members.

According to Frazier et al. (2015), incarcerated individuals confront various barriers during their rehabilitation and reintegration into society. For example, they confronted racism, a lack of family support, homelessness, unemployment, compulsive drug and alcohol use, an imbalance of mental health services, and a paucity of health care when reintegrating into the community. Thus, maintaining positive relationships with family, personal development, professional advancement, social activities, and a healthy lifestyle should be stressed to aid addicts throughout their lives in their rehabilitation (Matokrem, 2007). Intrapersonal difficulties that inhibit treatment and rehabilitation include an inability to cope with stress, low self-esteem, and manage interpersonal conflicts 
with family and others (Lee, Shin, \& Park, 2014; Tkacz et al., 2013). By contrast, Mirković-Hajdukov et al. (2017) revealed that a lack of familial support is the key factor that contributes to a person developing a heroin addiction.

Among the factors that become predictors of success in treatment and rehabilitation is the high awareness and readiness of addicts to change. Readiness for change is a concept that has been linked to success in the treatment and recovery process, particularly for drug users (Gannoni \& Goldsmid, 2017). A successful recovery process must begin with the addict's initial knowledge and readiness for change. Without a readiness for change, it is guaranteed that the drug rehabilitation process would fail miserably. The findings of a study conducted by Ibrahim et al. (2018) on 380 people referred to as PuS, that is, those who have completed a Cure and Care Rehabilitation Centre (CCRC) treatment programme and are currently supervised outside the institution was used to determine the likelihood of relapse and success in maintaining recovery among residents who have completed CCRC treatment and rehab. The findings of study 4 indicated that PuS included in the NADA observation phase demonstrated a low level of relapse tendency (emotional distress, social, environmental stress, family relationship conflict, and re-craving for drugs) that was manageable and not alarming. Indeed, researchers have discovered that PUS demonstrates a high level of drug-free self-efficacy. In addition, most PuS is also observed to use problem-solving strategies constructively in their daily lives, which predicts PuS's success in maintaining the recovery state.

Meanwhile, Freyer et al. (2004) discovered no correlation between treatment and an addict's readiness for change. They discovered that, although an addict has long and frequently received therapy and rehabilitation, the addict's level of readiness for change remains unchanged. This situation implies that an addict's lack of self-awareness regarding change contributes to their inability to change behaviour and thus maintain recovery. Blancard et al. (2003) discovered that drug users seek therapy because of a lack of motivation and readiness for change. Some addicts went to treatment based on the court or a particular organization mandated. This unreadiness has been cited as a reason for addicts' failure to fully recover from the effects of drugs, resulting in a multi-stakeholder discussion condemning drug rehabilitation institutes for failing to educate addicts.

\subsection{Family Function}

According to Fox (2015), social integration is a difficult process since recovering drug users must establish and maintain a positive sense of self, (ii) develop and maintain healthy relationships with family members, and (iii) avoid re-engaging in activities that violate social norms. However, Travis and Waul (2003) discovered that strong family support is crucial for persons just released from prison since family members' positive acceptance and emotional support can aid in social integration. As a result, family support is crucial for social integration.

Previously, Cullen (1994) suggested that family members' support and motivation is cost-effective in terms of increasing the individual's responsibility, (ii) fostering positive interaction between the individual and family members, (iii) fostering a loving bond between the individual and family members, and (iv) bolstering the individual's coping skills. According to Gómez et al. (2010), those who receive less support from family members experience emotions of isolation and loneliness and a sense of being disregarded by others. While Lopez et al. (2014) and Juan and José (2017) feel that a lack of support and motivation from family members contributes to an individual's re-engagement in criminal activity, this negatively influences their social integration process.

Former drug addicts have recovery characteristics when they have healthy family relationships, which have a significant favourable effect on the recovery retention process (Ibrahim et al., 2017). A recovering addict's relationship with their family would be robust and positive (Ghazalli et al., 2020). Thus, the more family support the recovering addicts receive, the more likely they will remain sober and avoid relapse (Hemovich, Lac \& Crano, 2011). Gilligan (1995) has shown that family support is crucial for developing strong bonds among family members and, consequently, strengthening family members' resilience when faced with stress and difficulties in life. While a study conducted by Bahr, Maughan, and Marcos (1998) indicated that family members with strong connections and bonds could assist keep children out of wrong settings such as drug abuse. On the other hand, bad relationships between family members can intensify family troubles and increase family members' risk of developing substance abuse disorders (Buehler, 2006).

\subsection{Religiosity}

Religious life or religiosity is critical in human life because religion and knowledge significantly impact an issue's receptivity to acceptance, the development of competitive human capital, and the establishment of commendable morals or attitudes. Additionally, it would affect behaviour, practices, and personality (Muhamad, 2006), life satisfaction and psychological well-being (Carlucci et al., 2015), morality (Aziz, 2021), and happiness 
(Ulfa \& Puspita, 2020). Mohamed, Che Din, and Ishak (1998) suggested that a lack of religious upbringing and family fragmentation substantially affects adolescents' drug use and abuse behaviours. Pfeiffer et al. (2018) suggested that religious belief is one of the most significant tools for resisting emotional and mental distress and health self-management. Adherence to unambiguous ideas and viewpoints based on religious teachings can help prevent teenagers from engaging in harmful and excessive free association.

Whereas Culver and Lundquist (2017) discovered that people who feel an attachment to the divine are more likely to feel positive about the direction and purpose of their lives. In addition, religious rituals among prisoners foster a constructive attitude toward cognitive and emotional rehabilitation. Finally, these adjustments can stimulate prosocial behaviour, preventing them from re-engaging in crime and facilitating their effective reintegration into society (Giordano et al., 2008).

According to Geppert, Bogenschuzt, and Miller (2007), most prior research has demonstrated a negative association between religious variables and addictive behaviour. It demonstrated that the stronger or more fervent an individual's religious convictions, the lower the likelihood of engaging in addictive behaviours. Grier and Gudiel (2011) have discussed how religion might act as a bulwark against various destructive behaviours, particularly among adolescents.

Religion can give social capital (caring and compassion) and social control to an individual. Thus, engaging in various religious activities such as praying, visiting houses of worship, and properly fulfilling all religious obligations indirectly cleanses an individual's soul, heart, and mind, causing them to be calmer, more inclined toward goodness and perpetually abstain from immoral acts. Those dissatisfied, abandoned, and rejected from society are observed to begin rebuilding hope when they feel accepted, loved, owned, helped, and cared for by God despite local community rejection (Inzlicht, Tullett, \& Good, 2012). Corwyn and Benda (2000) assert that frequent attendance at religious services is another religious activity that can persuade individuals to abstain from various risky behaviours, including drug use. Mohd Arifin (2017) concurs, adding that one of the criteria determining a religion's well-being is the notion that God loves oneself. The average PuS recognizes that they are still loved by God and believe in a God. Therefore, religiosity is found as one of the factors contributing to their ability to improve their behaviour and feel guilty about resuming drug use.

\subsection{Objective}

Therefore, since the readiness for change is an important factor in arranging effective treatment for addicts, this study was conducted to examine the relationship between readiness for change with family functioning and religiosity on individuals on surveillance (PuS) in NADA Jempol District, Negeri Sembilan, Malaysia. Specifically, the following hypotheses were tested:

1.3.1 There is a significant relationship between family functionality and readiness for change among PuS in NADA Jempol.

1.3.2 There is a significant relationship between religiosity and readiness for change among PuS in NADA Jempol.

\section{Method}

\subsection{Research Design}

This quantitative study uses a correlation study to examine the relationship between family functioning and religiosity with a readiness for change. A correlational research design investigates the relationships between family functionality and religiosity with the readiness for change among PuS in NADA Jempol. A correlation reflects the strength and or direction of the relationship between these three variables. The direction of a correlation can be either positive or negative. We choose this correlational design to determine whether there is a causal relationship between the variables. However, the researcher cannot influence the independent variable due to its impossibility, impracticability, or unethical nature. The survey method is used in this correlational research. It entails randomly selecting variables or participants in the research and completing a questionnaire based on the subjects of interest.

\subsection{Participants}

This study was conducted on 85 randomly selected samples among Persons under Surveillance (PUS). The study population in this study refers to the clients in a surveillance programme. It is limited to case studies in a single district, namely NADA Jempol, Negeri Sembilan, Malaysia. The study included various races who had completed the Cure \& Care Rehabilitation Centre (CCRC) treatment and rehabilitation programme, and they are currently involved in a 6-month surveillance programme. 


\subsection{Research Instruments}

The researcher used the questionnaire method as a research tool. The questionnaire used in this study had four parts, part A (Respondent Demographics), Part B (family function), Part C (religiosity), and Part D (readiness for change).

\subsubsection{Part A:}

Demographics of respondents. This part is a questionnaire related to the respondents' personal information. The researcher designed it to collect background information of the respondents. The items contained in section A are the respondent's personal information such as gender, age, race, religion, employment status, marital status, academic level, and material intake status.

\subsubsection{Part B:}

The Family Adaptation and Cohesion Scales III (FACES III) questionnaire measured the family function. Olson developed FACES III in 1983 to investigate family dynamics (Olson, Russell \& Sprenkle, 1983) and assess two significant dimensions on the circumplex model: adaptability and cohesion of the family. This measure assesses the degree to which family members are adaptive and attached to their family. In this study, all respondents involved had to answer all the questions according to the complete instructions in the questionnaire form provided. The FACES III instrument contains 20 items with a 5 Likert scale, ten odd-numbered items measuring cohesion, and ten even-numbered items measuring adaptability. The reliability of FACES III for the Malay version was $\alpha=0.80$ (Rohany et al., 2011)

\subsubsection{Part C:}

Universal Religiosity-Personality Inventory (URPI) Questionnaire is used in the study to measure religiosity. The questionnaire adapted to measure religiosity is the only instrument designed to measure religious practices according to mould and culture in Malaysia. This instrument is known as the Muslim Religiosity-Personality Inventory (MRPI), designed by Krauss, Hamzah, and Idris (2007). MRPI is tailored to Malaysian society comprising various religious and racial backgrounds through the Universal Religiosity-Personality Inventory (URPI). There are two dimensions measured through URPI, namely the dimensions of prosocial and ritual behaviour. The 20 items selected consisted of 10 items to measure prosocial behaviour and another ten items to measure ritual behaviour. A 5-point scale was used to measure religiosity from a range of 1 (never), 2 (rarely), 3 (sometimes), 4 (ever), and 5 (always). Cronbach's alpha values for each dimension exceeded 0.7.

\subsubsection{Part D:}

We used the University of Rhode Island's Change Assessment (URICA) to assess individuals' readiness to change. The URICA was developed and validated in 1983 by McConnaughy, Prochaska and Velicer, to classify subjects into the Stages of change in psychotherapy and can be used for health risk behaviours. This questionnaire has been translated into Malay and has demonstrated reliability with coefficient values greater than 0.70 in local research (Mohd Rafidi \& Abdul Halim, 2012; Tharbe et al., 2021). The URICA is a 32-item self-report measure comprised of four subscales that assess four distinct stages of change: Contemplation, Action, and Maintenance.

\subsection{Data Collection and Data Analysis}

To collect data, the researcher distributed and administered the questionnaire to the respondents. The researcher delivered questionnaires manually on-site, and time was allotted for 30 to 40 minutes. Inferential statistics were used to look at Pearson correlations to identify the relationship of family functioning and religiosity with the readiness for change. The data obtained from the instrument was processed using SPSS software version 26.

\section{Results}

A total of 85 respondents were involved in this study. They consisted of $80(94.1 \%)$ males and $5(5.9 \%)$ females. Then, there are three age categories, namely 21 - 30 years a total of 14 people (16.5\%), age category $31-40$ years is 51 people $(60 \%)$ and age category $41-50$ years people which is $13(15.3 \%)$ and 51 years category and above seven people $(8.2 \%)$. In terms of the Malay, the race was 79 (92.9\%), Chinese $3(3.5 \%)$, and Indian 3 patients (3.5\%). In terms of religious beliefs, 80 people are Muslims, (94.1\%) Buddhists 1 person (1.2\%) and Hindus 4 people $(4.7 \%)$. The distribution in terms of employment status was 59 people $(69.4 \%)$ employed, and 26 people (30.6\%) were unemployed. Meanwhile, in terms of marital status, the single category was 48 people (56.5\%), the married category was 28 people $(32.9 \%)$, and the divorced category was nine people $(10.6 \%)$. Then in terms of academic level, a total of 25 people (13.9\%) respondents are at the level of PMR / PT3, 17 people $(20.0 \%)$ are at the level of SPM, at the level of diploma, form 6 or matriculation is a total of 54 people (63.5\%). 
The degree level is eight people (9.4\%). As for the status of substance intake, for the category of continuous substance intake, 12 people $(14.1 \%)$ had stopped and took back 54 people $(63.5 \%)$ and continued to stop taking substances 19 people (22.4\%). Complete information of respondents as in Table 1.

Table 1. Demographic Data

\begin{tabular}{|c|c|c|}
\hline Item & Frequency $(\mathrm{n}=85)$ & Percentage (\%) \\
\hline \multicolumn{3}{|l|}{ Gender } \\
\hline Male & 80 & 94.1 \\
\hline Female & 5 & 5.9 \\
\hline \multicolumn{3}{|l|}{ Age } \\
\hline $21-30$ years & 14 & 16.5 \\
\hline $31-40$ years & 51 & 60 \\
\hline $41-50$ years & 13 & 15.3 \\
\hline 51years above & 7 & 8.2 \\
\hline \multicolumn{3}{|l|}{ Race } \\
\hline Malay & 79 & 92.9 \\
\hline Chinese & 3 & 3.5 \\
\hline Indian & 3 & 3.5 \\
\hline \multicolumn{3}{|l|}{ Religion } \\
\hline Islam & 80 & 94.1 \\
\hline Buddha & 1 & 1.2 \\
\hline Hindu & 4 & 4.7 \\
\hline \multicolumn{3}{|l|}{ Employment Status } \\
\hline Employed & 59 & 69.4 \\
\hline Unemployed & 26 & 30.6 \\
\hline \multicolumn{3}{|l|}{ Marital Status } \\
\hline Single & 48 & 56.5 \\
\hline Married & 28 & 32.9 \\
\hline Divorced & 9 & 10.6 \\
\hline \multicolumn{3}{|l|}{ Education Level } \\
\hline PMR / PT3 & 17 & 20.0 \\
\hline SPM & 54 & 63.5 \\
\hline Diploma/ Form. 6 / Matric & 8 & 9.4 \\
\hline Degree & 6 & 7.1 \\
\hline \multicolumn{3}{|l|}{ Continuous Substance Intake } \\
\hline Continuous use & 12 & 14.1 \\
\hline Stopped and took back & 54 & 63.5 \\
\hline Continue to stop & 19 & 22.4 \\
\hline
\end{tabular}

There are two hypotheses in this study:

3.1 There is a significant relationship between family functionality and readiness for change among PuS in NADA Jempol.

Table 2 . The relationship between family functioning and readiness for change.

\begin{tabular}{ccc}
\hline & Family Function & Readiness for Change \\
\hline Family Function & - & \\
Readiness for change & $.43^{* *}$ & - \\
\hline Note: $* *$ Correlation significant level at 0.05 (2-tailed) &
\end{tabular}

Note: ** Correlation significant level at 0.05 (2-tailed)

Table 2 shows the results of the relationship between family functionality and readiness for change. The results showed a positive relationship, $\mathrm{r}=0.43, \mathrm{n}=85 \mathrm{p}=0.00$ between family functionality with readiness for change. The relationship was significant because $\mathrm{p}<0.05$. The relationship also shows a low positive relationship because the correlation coefficient falls between 0.3 to 0.5 . Any change to family functionality results in a linear 
relationship of weak strength with change for readiness. Ha1 was accepted because there was a significant relationship between family functionality and readiness for change, but the relationship is weak.

There is a significant relationship between religiosity and readiness for change among PuS in NADA Jempol

Table 3 shows the results of the relationship between religiosity and readiness for change. The findings showed a positive relationship, $\mathrm{r}=0.27, \mathrm{n}=85 \mathrm{p}=0.01$ between religiosity with readiness for change and the relationship was significant $(\mathrm{p}<0.05)$. The correlation relationship also shows a very weak positive relationship because the correlation coefficient falls between 0.00 to 0.30 (Hinkle, Wiersma, \& Jurs 2003). Any change to religiosity would result in a linear relationship of very weak strength with change for readiness. Therefore, Ha2 was accepted because there was a significant relationship between religiosity and readiness for change, but the relationship is very weak.

Table 2 . The relationship between religiosity and readiness for change.

\begin{tabular}{ccc}
\hline & Religiosity & Readiness for Change \\
\hline Religiosity & - & \\
Readiness for change & $.27^{* *}$ & - \\
\hline
\end{tabular}

Note: **Correlation significant level at 0.05 (2-tailed)

\section{Discussion}

This study aimed to determine the relationship between family functioning, religion, and willingness to change. The findings suggested a little positive correlation between family functionality and readiness for change, while religion and readiness for change had a weak positive correlation. Thus, this study established the effect of family functioning and religiosity on the readiness of PuS in NADA Jempol to change. Although the connection between these two factors is small, they are inexorably intertwined in an individual's life. In summary, these findings educate the NADA, schools, and the general public on the importance of family and religion in each person. Inference analysis showed a significant relationship between functional family variables with the readiness for change low positive correlation. In contrast, the relationship between religiosity and readiness for change showed a significant relationship with a weak positive correlation.

The results showed a significant relationship between family functionality and readiness for change among PuS NADA Jempol. Although the study results showed a low positive relationship, there is still a relationship between family functionality and readiness for change. The research results found that the role of the family affects the readiness for change. Even so, the value of the relationship found is small. The result can be interpreted that many respondents have families that play a good role, but the family situation does not significantly impact the readiness for change. A similar finding by Blancard et al. (2003) found that drug addicts who received treatment lack high motivation and readiness for change. This situation may be because addicts present to receive treatment have been instructed by a court or a particular organization to receive drug treatment and rehabilitation. This coercion has been among the factors of addicts' failure to fully recover from drugs to the point of multi-stakeholder controversy pointing fingers at drug rehabilitation institutions perceived as failing to inject awareness into drug addicts (Wellish, Prondergast, \& Anglin, 1995).

According to Bowen's theory, a person with high self-differentiation can control their emotional system. They can differentiate emotions, thoughts and make decisions based on a combination of these two processes. (Kerr \& Bowen, 1988). A person with self-differentiation can balance the emotional and thought systems in every action and decision-making and consider the commonality of individuality funds appropriately. Friedman and Beschner (1985) reported that most drug addicts came from families divided due to divorce, separation or the death of the head of the family. A study based on Kulkarni and Biradar (2018) observations found that most abusers opined that family-related issues were the main reason for using substances. Russell's (1980) study found that children who received less love from their parents were more likely to engage in deviant behaviours, especially drug abuse. Low et al. (1996) also found that parents and their children agreed that unfulfilled needs such as 'not being respected recognized for one capabilities' and 'not being loved or treated fairly by parents' were causes of drug abuse. Drug addiction is a problem that is always given serious attention as this issue can affect the harmony of society and increase crime rates.

A study by Rahman et al. (2009) suggested that family members' and others' involvement in the addict rehabilitation process to ensure recovery can be realized. Furthermore, they found that the relationship problems with family members and girlfriends are also a source of recurring behaviour. The findings of this study are in line with the findings of a study conducted by Zeng and Tan (2021), suggest that family members should 
collaborate with drug addiction treatment centres and participate in the education and treatment process to help reduce drug relapse. The institution of the family is closely related to the self. Families who can still accept addicts as their members play a role in strengthening the addict's identity. In addition, the family is a very strong anchor because it is associated with the emotional attachment (emotional attachment) of the respondent to the family and the respondent is aware of the implications of their actions on their loved ones.

While the study's findings indicate a weak positive association, there is still a significant correlation between religion and willingness to change. The level of religion is moderate, as is the level of adaptability. Based on their findings, the researchers indicated that the initiative done by NADA in integrated the religious programming into their modules to assist PuS is a good effort. This finding is consistent with Galanter, Hansen and Potenza (2021) findings that religious or spiritually oriented drug rehabilitation programmes develop addicts' self-resilience and personal traits. Additionally, spiritual and religious programmes have been recognized to assist addicts in changing their drug-abandoning behaviours. According to Corwyn and Benda (2000), frequent worship at houses of worship is also a religious practice that might positively influence a person's decision to abstain from many harmful activities, including drug use. It can be concluded that religious or spiritual drug recovery programmes could more effectively mould addicts' personal qualities. Even spiritual and religious programmes have been identified as effective in assisting addicts in changing their drug-free behaviours.

Apart from that, PuS, who are improving in their life, can be seen through several recovery features, namely from religious or spiritual well-being, emotional management, and behaviour in the community. For example, a systematic review and meta-analysis study proved religious interventions' efficacy in helping people with substance use problems. (Hai et al., 2019). Furthermore, it showed that PuS who remain recovering would 'connect' to God because they know every action has a reward. This data is supported by several previous research stating that religion acts as a protective factor over drug addiction (Hodge, Cardenas, \& Montoya, 2001; Kulis et al., 2012) and is an important part of the recovery process (Grim \& Grim, 2019; Laudet et al., 2006; Walton-Moss, Ray, \& Woodruff, 2013).

Similarly, Ibrahim et al. (2017) concluded that spiritual and religious programmes could significantly assist addicts seeking to shift their behaviour away from narcotics. Possessing a high level of religious practice might instil confidence to continue evolving. They feel more at ease if PuS is more oriented toward religious programmes. Additionally, Salam, Wahab \& Ibrahim (2013) explained that when a Muslim submits to God through repentance and recitation of the Quran, the GSR (Galvanic Skin Response) changes, indicating a more positive emotional response. It is proposed that emotional regulation, concentration, and meditation with suitable sighs can improve psychophysiological performance. Psychospiritual-based treatment and rehabilitation approaches have a stronger tendency to stabilize recovery than drug-based approaches.

The link between religiosity and openness to change among PuS in NADA Jempol is also weak. This condition can be described by Bronfenbrenner's (1989) ecological systems theory, which states that a kid's growth occurs due to a reaction between the child and the environment. In this case, it is considered that the child's reaction to their environment affects the child's growth and development. According to the notions in this theory, whether we are aware or not that children are microsphere (centred in the middle) individuals, external circumstances can influence them. This religious experience is incorporated into the system that shapes a child's growth. The mesosystem incorporates this religious experience. A mesosystem is a response between microsystems in which problems in one microsystem affect the state of another microsystem. The readiness for change is moderate for PuS in NADA.

According to behavioural theory, this theory considers the environmental factors that cause behavioural problems and the effects of these behaviours. It involves many aspects of personal life. For example, spirituality and family relationships also need to be considered. Grier and Gudiel (2011) also noted that religion is a viable defence against various negative behaviours, particularly adolescents.

Religion can create a sense of security for social capital (caring and love) and individual social control. Thus, partaking in various religious activities such as praying, praying, visiting houses of worship, reading the book, and properly fulfilling all religious obligations would unwittingly purify one's soul, heart, and mind, allowing one to be calmer; loving goodness always steers clear of evil behaviours. Thus, the presence of religious programmes is a powerful deterrent to drug usage. For instance, increased attendance is connected with a decreased risk of marijuana usage (Bartkowski \& Xu, 2007). However, other studies have discovered that sporadic religious attendance is connected with an increased chance of drug use (Steinman, Ferketich \& Sahr, 2008). Thus, additional research is needed to evaluate how religious attendance explains drug use by affiliation and level of religious relevance. According to Palamar, Kiang and Halkitis (2014), individuals with a high 
religious presence may be protected from drug use; yet, religiosity is a personal feature that is difficult to change. While peers of the same denomination can inspire people to attend religious services more frequently, changing one's fundamental views is tough.

Future researchers should consider several study limitations. Given that the results are based on participants' self-reported data, it is feasible that the readiness behaviour questions were answered in a socially acceptable manner. Another drawback is the data's generalizability to other populations, as this study only looked at PuS in NADA, Jempol District, Negeri Sembilan, Malaysia. The selection of the future research samples might be expanded to include the NADA of other districts and states to see significant links. Furthermore, because there is little research on the subject, it can be further studied by including demographic data, self-esteem, loneliness, happiness, or life satisfaction. The researcher thinks that this approach would draw attention to the need for more research into substance abuse.

Furthermore, the amplitude of the associations between family support and religion (.42 to.25) fell within Cohen's (2009) limited range of significance. Thus, these correlations are significant enough to cause multicollinearity issues. Finally, due to the cross-sectional character of this study, no causal implications can be drawn from the findings.

\section{Acknowledgements}

The study was conducted according to the guidelines of the Declaration of Helsinki and approved by the Institutional Review Board of Universiti Putra Malaysia (UPM/FPP/TDPS/ERS5988. Date: 27/7/2020).

\section{References}

Aziz, A. A. (2021). Analysis of literature review on spiritual concepts according to the perspectives of the Al-Quran, Hadith and Islamic scholars. Turkish Journal of Computer and Mathematics Education (TURCOMAT), 12(9), 3152-3159. https://doi.org/10.17762/turcomat.v12i9.4790

Bahr, S. J., Maughan, S. L., Marcos, A. C., \& Li, B. (1998). Family, religiosity, and the risk of adolescent drug use. Journal of Marriage and the Family, 979-992. https://doi.org/10.2307/353639

Bartkowski, J. P., \& Xu, X. (2007). Religiosity and teen drug use reconsidered: A social capital perspective. American Journal of Preventive Medicine, 32(6), S182-S194. https://doi.org/10.1016/j.amepre.2007.03.001

Beschner, G. M., \& Friedman, A. S. (1985). Treatment of adolescent drug abusers. International Journal of the Addictions, 20(6-7), 971-993. https://doi.org/10.3109/10826088509047761

Blanchard, K. A., Morgenstern, J., Morgan, T. J., Labouvie, E., \& Bux, D. A. (2003). Motivational subtypes and continuous measures of readiness for change: Concurrent and predictive validity. Psychology of Addictive Behaviors, 17(1), 56. https://psycnet.apa.org/doi/10.1037/0893-164X.17.1.56

Bronfenbrenner, U. (1989). Ecological systems theory. In R. Vasta (Ed.), Six theories of child development: Revised formulations and current issues (pp. 187-250). Greenwich, CT: JAI Press.

Buehler, C. (2006). Parents and peers in relation to early adolescent problem behavior. Journal of Marriage and Family, 68(1). https://doi.org/10.1111/j.1741-3737.2006.00237.x

Carlucci, L., Tommasi, M., Balsamo, M., Furnham, A., \& Saggino, A. (2015). Religious fundamentalism and psychological well-being: An Italian study. Journal of Psychology and Theology, 43(1), 23-33. https://doi.org/10.1177\%2F009164711504300103

Corwyn, R. F., \& Benda, B. B. (2000). Religiosity and church attendance: the effects on use of "hard drugs" controlling for sociodemographic and theoretical factors. The International Journal for the Psychology of Religion, 10(4), 241-258. https://doi.org/10.1207/S15327582IJPR1004_03

Cullen, F. T. (1994). Social support as an organizing concept for criminology: Presidential address to the Academy of Criminal Justice Sciences. Justice Quarterly, 11(4), 527-559. https://doi.org/10.1080/07418829400092421

Culver, J., \& Lundquist Denton, M. (2017). Religious attachment and the sense of life purpose among emerging adults. Religions, 8(12), 274. https://doi.org/10.3390/rel8120274

Fox, K. J. (2015). Theorizing community integration as desistance-promotion. Criminal justice and behavior, 42(1), 82-94. https://doi.org/10.1177\%2F0093854814550028

Frazier, B. D., Sung, H. E., Gideon, L., \& Alfaro, K. S. (2015). The impact of prison deinstitutionalization on community treatment services. Health \& Justice, 3(1), 1-12. https://doi.org/10.1186/s40352-015-0021-7 
Freyer, J., Tonigan, J. S., Keller, S., John, U., Rumpf, H. J., \& Hapke, U. (2004). Readiness to change versus readiness to seek help for alcohol problems: the development of the Treatment Readiness Tool (TReaT). Journal of studies on alcohol, 65(6), 801-809. https://doi.org/10.15288/jsa.2004.65.801

Galanter, M., Hansen, H., \& Potenza, M. N. (2021). The role of spirituality in addiction medicine: A position statement from the spirituality interest group of the international society of addiction medicine. Substance Abuse, 1-3. https://doi.org/10.1080/08897077.2021.1941514

Gannoni, A., \& Goldsmid, S. (2017). Readiness to change drug use and help-seeking intentions of police detainees: Findings from the DUMA program. Trends and issues in crime and criminal justice, (520), 1-17. Retrieved from https://www.aic.gov.au/publications/tandi/tandi520

Geppert, C., Bogenschutz, M. P., \& Miller, W. R. (2007). Development of a bibliography on religion, spirituality, and addictions. Drug and alcohol review, 26(4), 389-395. https://doi.org/10.1080/09595230701373826

Ghazalli, F. S. M., Ghani, N. A., Abdullah, B., Chik, W. M. Y. W., Ramly, A. F., \& Zabudin, A. A. M. (2020). Form of Familial Hindrances in Supporting the Rehabilitation of Opiate Addict in the State of Terengganu. Asian Journal of Civilizational Studies (AJOCS), 2(2), 1-16. Retrieved from http://www.ajocs.com/index.php/ajocs/article/view/40

Gilligan, R. (1995). Family support and child welfare: Realizing the Promise of the Child Care Act. On Behalf of the Child: Child Welfare, Child Protection, and the Child Care Act. Dublin: Farmer.

Giordano, P. C., Longmore, M. A., Schroeder, R. D., \& Seffrin, P. M. (2008). A life-course perspective on spirituality and desistance from crime. Criminology, 46(1), 99-132. https://doi.org/10.1111/j.1745-9125.2008.00104.x

Gómez Botero, M., Arango Tobón, E., Molina González, D., \& Barceló, E. (2010). Characteristics of theory in conduct disorder. Psicología desde el Caribe, (26), 103-118. Retrieved from https://www.redalyc.org/articulo.oa?id=21319039006

Grier, L., \& Gudiel, W. (2011). Can religious beliefs combat negative peer influence during adolescence? Mental Health, Religion \& Culture, 14(10), 983-997. https://doi.org/10.1080/13674676.2010.542452

Grim, B. J., \& Grim, M. E. (2019). Belief, behavior, and belonging: How faith is indispensable in preventing and recovering from substance abuse. Journal of religion and health, 58(5), 1713-1750. https://doi.org/10.1007\%2Fs10943-019-00876-w

Hai, A. H., Franklin, C., Park, S., DiNitto, D. M., \& Aurelio, N. (2019). The efficacy of spiritual/religious interventions for substance use problems: A systematic review and meta-analysis of randomized controlled trials. Drug and alcohol dependence, 202, 134-148. https://doi.org/10.1016/j.drugalcdep.2019.04.045

Hemovich, V., Lac, A., \& Crano, W. D. (2011). Understanding early-onset drug and alcohol outcomes among youth: The role of family structure, social factors, and interpersonal perceptions of use. Psychology, health \& medicine, 16(3), 249-267. https://doi.org/10.1080/13548506.2010.532560

Hinkle, D. E., Wiersma, W., \& Jurs, S. G. (2003). Applied statistics for the behavioral sciences (Vol. 663). Houghton Mifflin College Division.

Hodge, D. R., Cardenas, P., \& Montoya, H. (2001). Substance use: Spirituality and religious participation as protective factors among rural youths. Social Work Research, 25(3), 153-161. https://doi.org/10.1093/swr/25.3.153

Ibrahim, F., Zakaria, E., Nen, S., Sarnon, N., \& Hassan, N. (2018). Pengaruh Gangguan Emosi Dalam Kalangan Orang Kena Pengawasan (Influence of Emotional Disturbance among Individuals under Surveillance). Jurnal Psikologi Malaysia, 32(4). Retrieved from http://spaj.ukm.my/ppppm/jpm/article/view/428

Ibrahim, F., Zakaria, E., Saim, N. J., Nen, S., \& Sani, M. N. M. (2017). Faktor-faktor penyumbang ketahanan diri penagih untuk pulih bebas dadah. e-BANGI, 12(1), 60-74. Retrieved from https://ejournal.ukm.my/ebangi/article/view/18296

Inzlicht, M., Tullett, A. M., \& Good, M. (2012). The need to believe: a neuroscience account of religion as a $\begin{array}{lllll}\text { motivated process. Religion, Brain \& } & \text { Behavior, } 192-212 .\end{array}$ https://doi.org/10.1080/2153599X.2011.647849

Jasni, A., Ah, S. H. A. B., Yusoff, J. Z. M., Shahid, K. M., Omar, N., \& Azman, Z. (2018). Faktor penghijrahan dan penumpuan bekas banduan di Jalan Chow Kit, Kuala Lumpur (Factor of migration and convergence of former prisoners in Chow Kit Road, Kuala Lumpur). Geografia-Malaysian Journal of Society and Space, 
14(1). Retrieved from http://journalarticle.ukm.my/12587/1/18336-69413-1-PB.pdf

Juan, M. F. C., \& José, M. A. P. (2017). Study to investigate the links between crimes committed by youth offenders and the nature of their migratory movements. Procedia - Social and Behavioral Sciences, 237, 505-510. https://doi.org/10.1016/j.sbspro.2017.02.099

Jusoh, M. R., Mohd Hussin, A. H., \& Abdul Ghani, S. (2015). Keberkesanan terapi kelompok psikopendidikan dalam meningkatkan motivasi penagih dadah. Jurnal Anti Dadah Malaysia Jilid, 9. Retrieved from https://www.adk.gov.my/wp-content/uploads/KEBERKESANAN-TERAPI-KELOMPOK-PSIKOPENDIDI KAN.pdf

Kerr, M. E., Bowen, M., \& Kerr, M. E. (1988). Family evaluation. WW Norton \& Company.

Krauss, S., Hamzah, A., \& Idris, F. (2007). Adaptation of a Muslim Religiosity Scale for Use with Four Different Faith Communities in Malaysia. Review of Religious Research, 49(2), 147-164. Retrieved from http://www.jstor.org/stable/20447486

Kulis, S., Hodge, D. R., Ayers, S. L., Brown, E. F., \& Marsiglia, F. F. (2012). Spirituality and religion: Intertwined protective factors for substance use among urban American Indian youth. The American journal of drug and alcohol abuse, 38(5), 444-449. https://doi.org/10.3109/00952990.2012.670338

Kulkarni, R. K., \& Biradar, M. K. (2018). Socio-demographic profile of substance user in the de-addiction centre. Indian Journal of Forensic and Community Medicine, 5(3), 193-196. https://doi.org/10.18231/2394-6776.2018.0044

Laudet, A. B., Morgen, K., \& White, W. L. (2006). The role of social supports, spirituality, religiousness, life meaning, and affiliation with 12-step fellowships in quality of life satisfaction among individuals in recovery from alcohol and drug problems. Alcoholism treatment quarterly, 24(1-2), 33-73. https://doi.org/10.1300\%2FJ020v24n01_04

Lee, H., Shin, S. K., \& Park, S. Y. (2014). Effects of a therapeutic community on Korean substance abusers in prison. Journal of Social Service Research, 40(4), 481-490. https://doi.org/10.1080/01488376.2014.922401

Lopez, F., Carpintero, E., Campo, A., Lazaro, S., \& Soriano, S. (2011). Program for Juvenile Offenders: Educational and Therapeutic Intervention. Madrid: Pirámide.

Low, W. Y., Zulkifli, S. N., Yusof, K., Batumalail, S., \& Aye, K. W. (1996). The drug abuse problem in Peninsular Malaysia: Parent and child differences in knowledge, attitudes, and perceptions. Drug and alcohol dependence, 42(2), 105-115. https://doi.org/10.1016/0376-8716(96)01265-3

Matokrem, L. (2007). Intervensi dan peranan kaunselor untuk menjana kepulihan klien sepanjang hayat. Jurnal Antidadah Malaysia, 1(1), 97-118.

Mirković-Hajdukov, M., Spahić, T. E., Softić, R., Bećirović, E., \& Šimić, J. (2017). Family atmosphere and relationships as predictors of heroin addiction. Psychiatria Danubina, 29(2), 129-33. https://pubmed.ncbi.nlm.nih.gov/28492220/

Mohamed, M. N., Che Din, S., \& Ishak, I. (1998). Keberkesanan Rawatan dan Pemulihan Penagihan Dadah: Modaliti Kerohanian dan Tradisional di Malaysia. Sintok: Universiti Utara Malaysia.

Mohd Ariffin, N. (2017). Kesejahteraan Agama dalam Kalangan Bekas Pengguna Dadah (BPD) bagi Mengurangkan Risiko Pengulangan Dadah. Jurnal Pembangunan Sosial, 20, 171-188. https://doi.org/10.32890/jps.20.2017.11538

Muhamad, R. (2006). Religiosity and moral judgement: An empirical investigation among Malay Muslims in Malaysia. Jurnal Syariah, 14(2), 87-101. Retrieved from https://ejournal.um.edu.my/index.php/JS/article/view/22809

National Anti-Drug Agency (NADA) Malaysia. (2018) Yearly Report 2017. Ministry of Home Affairs, Malaysia. Retrieved from www.adk.gov.my

Olson, D. H., Portner, J., \& Lavee, Y. (1985). Family adaptability and cohesion evaluation scales (FACES III). St. Paul: University of Minnesota, Family Social Science.

Olson, D. H., Russell, C. S., \& Sprenkle, D. H. (1983). Circumplex model of marital and family systems: Vl. Theoretical update. Family Process, 22(1), 69-83.

Othman, Z., Idris, N. A., \& Druis, M. D. (2017). Penyalahgunaan dadah sebagai ancaman keselamatan: Analisis keberkesanan program kerajaan dalam mengekang pengrekrutan penagih dadah di Malaysia (Illicit drugs as 
a security threat: An analysis of state-run programmes to curb drug addict recruitment in Malaysia). Geografia-Malaysian Journal of Society and Space, 11(13). Retrieved from https://ejournal.ukm.my/gmjss/article/view/19115

Palamar, J. J., Kiang, M. V., \& Halkitis, P. N. (2014). Religiosity and exposure to users in explaining illicit drug use among emerging adults. Journal of religion and health, 53(3), 658-674. https://doi.org/10.1007/s10943-012-9660-3

Pfeiffer, J., Li, H., Martez, M., \& Gillespie, T. (2018). The role of religious behavior in health self-management: A community-based participatory research study. Religions, 9(11), 357. https://doi.org/10.3390/rel9110357

Rahman, W. R. A., Dzulkifli, M. A., Dawood, S. R. S., \& Mohamad, M. (2009). Social support among Malay, Chinese, and Indian drug addicts in Malaysia. Jurnal Agensi Anti Dadah Kebangsaan, 5(1), 1-38. Retrieved from https://www.adk.gov.my/wp-content/uploads/5_5.pdf

Rohany, N., Ahmad, Z. Z., Rozainee, K., \& Shahrazad, W. W. (2011). Family functioning, self-esteem, self-concept and cognitive distortion among juvenile delinquents. The Social Sciences, 6(2), 155-163.

Russell, J. A. (1980). A circumplex model of affect. Journal of personality and social psychology, 39(6), 1161. https://psycnet.apa.org/doi/10.1037/h0077714

Salam, U. B., Wahab, M. N. A., \& Ibrahim, A. B. (2013). Potentiality of taubah (Islamic repentance) and listening to the Holy Quran recitation on galvanic skin response. International Journal of Psychology and Counselling, 5(2), 33-37. https://doi.org/10.5897/IJPC12.034

Steinman, K. J., Ferketich, A. K., \& Sahr, T. (2008). The dose-response relationship of adolescent religious activity and substance use: Variation across demographic groups. Health Education \& Behavior, 35(1), 22-43. https://doi.org/10.1177\%2F1090198105284839

Tharbe, I. H. A., Kamaruddin, M. K. A., Sumari, M., \& Chong, I. M. (2021). Data on the relationship of emotional intelligence and stages of change among Malaysian prison inmates. Data in Brief, 35, 106804.

Tkacz, J., Severt, J., Cacciola, J., \& Ruetsch, C. (2013). Compliance with buprenorphine medication-assisted treatment and relapse to opioid use. The Journal on Addictions, 21, 55-62. https://doi.org/10.1111/j.1521-0391.2011.00186.x

Travis, J., \& Waul, M. (2003). Prisoners once removed: The impact of incarceration and re-entry on children, families and communities. Washington, DC: Urban Institute

Ulfa, M., \& Puspita, E. D. A. (2020). Pursuing Happiness in Modern Era; Study On Hamka's Perspective. Tasfiyah: Jurnal Pemikiran Islam, 4(1), 1-26. https://doi.org/10.21111/tasfiyah.v4i1.3960

Walton-Moss, B., Ray, E. M., \& Woodruff, K. (2013). Relationship of spirituality or religion to recovery from substance abuse: A systematic review. Journal of addictions nursing, 24(4), 217-226. https://doi.org/10.1097/jan.0000000000000001

Wellisch, J., Prendergast, M. L., \& Anglin, M. D. (1995). Toward a drug abuse treatment system. Journal of Drug Issues, 25(4), 759-782. https://doi.org/10.1177\%2F002204269502500408

Zeng, X., \& Tan, C. (2021). The relationship between the family functioning of individuals with drug addiction and relapse tendency: A moderated mediation model. International Journal of Environmental Research and Public Health, 18(2), 625. https://doi.org/10.3390/ijerph18020625

\section{Copyrights}

Copyright for this article is retained by the author(s), with first publication rights granted to the journal.

This is an open-access article distributed under the terms and conditions of the Creative Commons Attribution license (http://creativecommons.org/licenses/by/4.0/). 